Karmazin György ${ }^{1}$

\title{
Logisztikai szolgáltató központok fejlesztése hálózati kutatások eredményeinek felhasználásával
}

\author{
Karmazin, György \\ The Development of Logistics Service Centres through the Use of Results in Network \\ researches
}

\begin{abstract}
Összefoglaló:
A nagy árumegállító és hozzáadott értéket létrehozó logisztikai központok kialakulásával olyan hálózati csomópontok jöttek létre az együttmüködö szervezetekben, amelyek különbözö közlekedési útvonalak és alágazati pályák, infrastrukturális és informatikai összekötésével megvalósitják az ellátási láncok (hálók) menedzsmentjét. Az üzleti hálózatokban megjelenö logisztikai központok hatékony müködtetését általában logisztikai szolgáltató (3PL/4PL) vállalkozások végzik. Az ellátási hálókat komplex hálózatként értelmezve, a logisztikai központokat (HUB) csomópontoknak, a központokat összekötö útvonalakat és kapcsolatokat pedig a hálózatelméletben használt fogalom átvételével, éleknek nevezhetjük. Barabási hálózatkutatási eredményeit figyelembe véve keresünk összefüggéseket az általa bizonyított törvényszerüségek és a logisztikai rendszerekben található szolgáltatók által üzemeltetett központok (HUB) növekedési lehetöségei között.
\end{abstract}

Kulcsszavak: állati és emberi csoportok, üzleti hálózatok, vállalati méret, logisztikai hubok, stratégia megvalósítását támogató tevékenységek

\section{Abstract:}

Logistics centres of a huge capacity and ability to create added value have emerged in recent decades. These centres have become network nodes among the co-operating organizations which accomplish the management of supply chains by connecting different modalities and networks with their infrastructure and informatics. The effective operation of logistics centres present in business networks are usually managed by logistics supplier businesses (3PL/4PL). Defining the supply net as a complex network, logistics centres may be called hubs, the routes and relationships connecting the centres - by borrowing the term used in network theory - may be called edges. Taking into consideration the results of Barabási's network research we are searching for correlations between his proven principles and the growth possibilities of the centres (hubs) operated by logistics service providers.

Keywords: animal and human groups, business networking, business size, logistics hubs, activities supporting the implementation of the strategy

\section{BEVEZETÉS}

Minden korszaknak megvan az az időszaka, hogy mit lehet és mit érdemes kutatni. A hálózat az a kihívás, amit érdemes most

\footnotetext{
${ }^{1}$ Főiskolai adjunktus, Ph.D., Szolnoki Főiskola, alapító-tulajdonos, BI-KA Logisztika Kft., karmazin.gyorgy@bi-ka.hu
}

felvállalni. Úgy a biológiai egzisztenciánk, mint a kommunikációnk, a szakmai életünk és a társadalmi életünk is hálózatoktól függ. Ezeknek a megértése nem csak szükségszerű a tudósok és a hétköznapi emberek számára, hanem elengedhetetlen is, hiszen valamilyen módon navigálnunk kell a 21. századot. A jövő technológiái, a jövőbeli kommunikációnk és az 
egész biológiai létezésünk a hálózatoktól fog függeni. A 21. században jelen vannak a hálózatok, és mi teljesen tőlük függünk, hiszen beléjük vagyunk ágyazódva. Számunkra ez egy olyan kérdéssé vált, hogy már nem lehet hálózatok nélkül „rácsodálkozni” a világra (Barabási, 2014a, interjú alapján). Az ember az őt körülvevő természettel szimbiózisban él, bár ezzel folyamatosan visszaél (környezetszennyezés), amiért egyre gyakrabban büntet is a természet (természeti katasztrófák).

Magunkon is tapasztalhatjuk, hogy ha minél többet tartózkodunk a természetben, minél több megfigyelést végzünk például az állatok életével kapcsolatban, annál több, az emberiség számára is hasznosítható törvényszerüségre jöhetünk rá. Így van ez a hazai hálóelméleti kutatásokat végző kutatókkal is, akik a galambok mozgásából, és a vizsgált madárfaj egyedei közötti kapcsolat megfejtéséből vonnak le, az emberi közösségek fejlesztése számára is hasznosítható összefüggéseket (Vicsek, 2014), illetve a jövő technológiai fejlődésének irányait támogató megoldásokat (például a drónokkal való kísérletek az Alibaba, az Amazon, a Google és a logisztikai piacon múködő UPS vállalatok keretein belül). Érdekesség, hogy a Google vállalat drónokkal kapcsolatos tesztjeit az Amerikai Egyesült Államok nem engedélyezi az USA területén, így azt kénytelen Ausztráliában elvégezni (Világgazdaság, 2015). természetben az állatok legnagyobb többsége csoportokban él, úgy ahogy mi emberek is különböző közösségekben éljük a hétköznapjainkat. Ma már szinte közhelynek számít az a megállapítás, hogy egy összetartó (munka) közösség sokkal erősebb és jobb válaszokat tud adni a változó világ új kihívásaira, mint egy egyén. Bár mi magyarok a munkavégzésünk során rosszul állunk a csoportmunka sikerébe vetett hitünkkel és teljesítményünkkel. Egy friss kutatási eredmény szerint a hazai munkavállalók $50 \%$-a szerint teljesít csak jobban, ha csoportban dolgozik, mint egyénileg. Ráadásul a hazai csoportmunka tagjainak sokszínúségbeli összetétele is jellemzően eltér a más kultúrákban elfogadottakétól (Randstad, 2014; Adó Online, 2014).

\section{2. ÜZLETI HÁLÓZATOK}

A globális gazdaság kvázi szerkezetét üzleti hálózatok adják (Gelei, 2008), melyek a változó gazdasági környezet hatására jöttek létre, majd a hálózatosodás eredményeképpen jelentős versenyelőnyre is szert tehettek a vállalatok. „A hálózat - s így az üzleti hálózat is - egy struktúra, melyben számos csomópont számos szálon keresztül kapcsolódik egymáshoz. A csomópontok az üzleti hálózatokban az egyes üzleti egységek, mint például termelő vállalatok, vevők, logisztikai vagy éppen pénzügyi szolgáltatók. Az összekötő szálak pedig e csomópontok közötti kapcsolatként értelmezhetők" (Gelei, 2008, 4. o.). Az üzleti hálózatok kialakulásának gyökereit Japánban találhatjuk meg, ahol a keiretsu-k egy-egy nagybank finanszírozásának támogatásával, jelentős beszállítói kapcsolatokkal rendelkező nagyvállalat köré szerveződve végzik tevékenységüket (Fukuyama, 2007). A nemzetközi modelleket vizsgálva és ismerve a hazai vállalkozások méretbeli eloszlását (KSH, 2014), csak bizakodhatunk abban, hogy a magyar kis-és középvállalatok, a globalizálódó üzleti hálózatok részeként boldogulni fognak (Gelei, 2008).

\section{LOGISZTIKA ÉS A HÁLÓZATOK}

Természetesen nem csak a termelői kapcsolatokban, hanem a logisztikai szemlélet megjelenése óta, a gazdaságra általánosan is hálózatként kell tekinteni (Chikán, 2002 in Egri, 2014). A nagy árumegállító és hozzáadott értéket létrehozó logisztikai központok kialakulásával olyan hálózati csomópontok jöttek létre az együttmúködő szervezetekben, amelyek különböző közlekedési útvonalak és alágazati pályák, infrastrukturális és informatikai összekötésével, megvalósítják az ellátási láncok (hálók) menedzsmentjét. Ezeknek a rendszereknek az információ áramlását jelentősen támogatja az internet, a 
hatékonyságát pedig nagyban növeli az innovációs és a technológiai fejlesztések alkalmazása. Az üzleti hálózatokban megjelenó logisztikai központok hatékony működtetését általában logisztikai szolgáltató (3PL/4PL) vállalkozások végzik, amelyek stratégiai elképzeléseikben is a hálózatos elrendezésú formát részesítik előnyben (Duleba, 2009). Az ellátási hálókat komplex hálózatként értelmezve, a logisztikai központokat (HUB) csomópontoknak, a központokat összekötó útvonalakat és kapcsolatokat pedig a hálózatelméletben használt fogalom átvételével, éleknek nevezhetjük. Elfogadva Barabási állítását, miszerint a „komplex hálózatok mögött valószínúleg léteznek törvények" (Barabási, 2013, 82. o.), keressünk összefüggéseket az általa bizonyított törvényszerűségek és a logisztikai rendszerekben található szolgáltatók által üzemeltetett központok (HUB) növekedési lehetőségei között.

A statikus, véletlenszerúen felépült hálózatok bemutatását elhagyva, figyelmünket a dinamikusan növekvő, skálafüggetlen hálózatok vizsgálatainak eredményeire fordítjuk!

\section{HÁLÓZATI PONTOK NÖVEKEDÉSE}

Barabási első megállapítása a „népszerúség alapján történő kapcsolódás" elfogadását mondja ki, miszerint szívesebben választjuk ki azt a csomópontot, amelynek például kétszer annyi linkje (kapcsolata) van, mint egy másiknak. A folyamatosan növekvő dinamikus, skálafüggetlen hálózatoknak és a népszerűsító kapcsolódásnak köszönhetően „néhány sok kapcsolattal rendelkező középpont keletkezik (Barabási, 2013, 99. o.) Ezt nevezhetjük második megállapításnak is, melynek következménye az, hogy „a hálózat növekedésével a korábbi pontoknak több idejük van kapcsolatok szerzésére, mint a később jövőknek" (Barabási, 2013, 99. o.) Ezt elnevezhetjük az „időben való belépés" előnyének, amely a fenti két szabályosság hatásainak köszönhetően jelentősen hozzájárul egy középpont növekedéséhez.
De mi lesz a későn jövőkkel, akik koruknál vagy ötletüknél fogva később lépnek be egy már múködő üzleti hálózatba? Megvizsgálva azt a folyamatot, amely elválasztja a győzteseket a vesztesektől, láthatjuk, hogy a komplex rendszerekben megjelenő verseny esélyt ad a jobban alkalmazkodó vállalkozásoknak (esetünkben pontoknak) arra, hogy „fitségüknek” köszönhetően előnyre tegyenek szert a versenytársaikkal (akár régebbi pontokkal) szemben (Barabási, 2014b). Ezt nevezhetjük az alkalmasság szabályának, amely alapjában „nem szünteti meg a növekedési és a népszerűségi kapcsolódást" (Barabási, 2013, 109. old) szabályzó mechanizmusokat. Visszatérve a természethez láthatjuk, hogy a legtöbb élő rendszer képes arra, hogy nagyon eltérő környezeti feltételek estén is életben maradjon (Barabási, 2013), ellenben az ember által múködtetett rendszerekben gyakran előfordul az, hogy a legkisebb meghibásodások hatására is múködésképtelenné válik például egy ember által előállított szerkezet. Ebből kifolyólag a robusztusság (hibatűrő képesség) vizsgálata a jövőben fontos tanulságokkal járhat a múködőképességre vonatkozóan, hiszen minden rendszernek a múködőképességét „egy bonyolult, szorosan összefüggő hálózat garantálja" (Barabási, 2013, 125. o.).

A fenti szabályok figyelembe vételével ma már Barabási és csoportja vállalkozik arra, hogy egy adott dinamikus, skálafüggetlen hálózatról megmondja, hogy „a gazdag egyre gazdagabb lesz" vagy a "győztes mindent visz" sémát követi. Nézzük meg, milyen párhuzamot vonhatunk le a fenti szabályosságok, valamint a logisztikai szolgáltatók stratégiaválasztása és növekedési lehetőségei között.

\section{PÁRHUZAMOK ÉS JAVASLATOK}

A globális áruforgalom töretlen növekedése és az e-kereskedelmi forgalom előrejelzései és töretlen népszerúsége - csak Kínában évi 20\%os növekedést prognosztizálnak ezen a területen 2019-ig - (Forrester, 2015) folyamatosan biztosítja a világot átszövő logisztikai hálózatok dinamikus fejlődését, tehát 
a fenti megállapításokat elfogadhatjuk a logisztikai rendszerekre vonatkozóan is. Az 1. táblázat összefoglalja a hálózatelmélet eredményeit és általános következtetéseit, illetve a logisztikai központokat működtető logisztikai szolgáltatókra vonatkozó, növekedésben elkötelezett, üzleti stratégiákat támogató tevékenységekre vonatkozó javaslatokat.
A javaslatok alapját a hazai logisztikai szolgáltatók körében végzett empirikus, primer, reprezentatív kutatás eredményei (Karmazin, 2014), a szerző saját, logisztikai vállalatnál szerzett gyakorlati tapasztalatai, a szakcikk megírása során felhasznált hazai és nemzetközi kutatási eredmények és tudományos publikációk következtetései adják.

\begin{tabular}{|c|l|}
\hline Hálózati pont fejlődése & \multicolumn{1}{|c|}{$\begin{array}{c}\text { Logisztikai szolgáltatók stratégiáit megvalósító támogatói } \\
\text { tevékenységek }\end{array}$} \\
\hline \multirow{2}{*}{ népszerűség } & $\begin{array}{l}\text { hatékony PR és marketing tevékenység, magas szakmai színvonalra } \\
\text { való törekvés, nyitottság a környezet felé, bizalomszint emelése az } \\
\text { üzleti kapcsolatokban, új ágazatok felé nyitás, új kapcsolatok } \\
\text { kialakítása az internet támogatásával }\end{array}$ \\
\hline középpont (nagyság) & $\begin{array}{l}\text { növekedési stratégia elfogadtatása a vállalati szervezeten belül, } \\
\text { együttmúködések kialakítása, akár konkurens vállalatokkal is, } \\
\text { stratégiai felvásárlások }\end{array}$ \\
\hline időben való belépés & $\begin{array}{l}\text { rugalmasság, okozói magatartás, új piacokra lépés, új szolgáltatások } \\
\text { és technológiák bevezetése, alkalmazása }\end{array}$ \\
\hline alkalmasság & $\begin{array}{l}\text { változásra való képesség fejlesztése, ágazatspecifikus-informatikai } \\
\text { fejlesztések, folyamatos képzés, nyitottság az újdonságok irányába }\end{array}$ \\
\hline robusztusság & $\begin{array}{l}\text { ISO magas szintú alkalmazása, javító mechanizmus beépítése az } \\
\text { üzleti folyamatokba (PDCA ciklus), bevonás, delegálás, döntések } \\
\text { alacsonyabb szintre engedélyezése, széles szolgáltatás- és vevői } \\
\text { (iparági) portfólió }\end{array}$ \\
\hline
\end{tabular}

1. táblázat: A hálózati pontok fejlődése és a logisztikai szolgáltatók stratégiáit megvalósító támogatói tevékenységek összefüggései

Forrás: saját szerkesztés, 2014

\section{6. ÖSSZEFOGLALÁS}

A fenti szakcikk tanulságaként leírhatjuk, hogy „a hálózatelmélet a logisztika hasznos eszköztárává tud válni, amely a nemzetközi logisztika, a termeléslogisztika, a globális gazdasági folyamatokban mind jobban felismerhetővé teszi az optimális elrendeződéseket, és a kapcsolatok lerövidítésével a gazdasági hatékonyság fokozójává válik" (Egri, 2014).

Ezen új hatások jelentős szerepet fognak gyakorolni a hazai logisztikai szolgáltatók stratégiájára is.
A logisztikai szolgáltató vállalkozások vizsgálatával foglalkozó honi (Karmazin, 2014) és nemzetközi kutatások (Kotonen, 2012) több oldalról is vizsgálták és keresték, a logisztikai piac szereplőinek stratégiaválasztásának és képességfejlesztésének lehetőségeit, ellenben a fenti szakcikkben feldolgozott hálózatelméleti megközelítés és következtetés, új szemléletet hozhat a magyar logisztikai központokat múködtető, hazai logisztikai szolgáltató vállalatok döntéshozói számára. 
Karmazin György

\section{FELHASZNÁLT IRODALOM}

[1] Adó Online (2014): Nem csapatjátékos a magyar. http://ado.hu/rovatok/munkaugyek/nem-csapatjatekos-a-magyar (letöltés dátuma: 2014.12.04.)

[2] Barabási, A. L. (2013): Behálózva. A hálózatok új tudománya. Helikon Kiadó, Budapest. 82, 99, 109, 125. o.

[3] Barabási, A. L. (2014a): http://www.mediaklikk.hu/2014/12/06/nezze-ujra-primaprimissima-2014/, (letöltés dátuma: 2014.12.07.)

[4] Barabási, A. L. (2014b): Behálózva. Üzleti Gondolkodók Klubján elhangzott előadás, Budapest, 2014. október 8.

[5] Duleba, Sz. (2009): Az AHP módszer egy lehetséges alkalmazása trendek előrejelzésére. Szigma. XL évfolyam, 3-4 szám, 41-43. o.

[6] Egri, I. (2014): Hálózatok és logisztika. Duleba Szabolcs (szerk.): Logisztikai évkönyv 2015, Magyar Logisztikai Egyesület, Budapest, 27-33. o.

[7] Forrester (2015): China Online Retail Forecast, 2014 To 2019. Embrace The Mobile Sales Momentum In China, 2015.02.04.

[8] https://www.forrester.com/China+Online+Retail+Forecast+2014+To+2019/fulltext/-/ERES118544 (letöltés dátuma: 2015.02.09.)

[9] Fukuyama, F. (2007): Bizalom - A társadalmi erények és a jólét megteremtése. Európa Könyvkiadó, Budapest, 17-513. o.

[10] Gelei, A. (2008): Hálózat - a globális gazdaság kvázi szervezete. 95. sz. Múhelytanulmány, Budapesti Corvinus Egyetem Vállalatgazdaságtan Intézet, 2008. június

[11] Karmazin, Gy. (2014): A logisztikai szolgáltató vállalatok gazdálkodási sikertényezőinek és stratégia-választásának hatása a vállalat eredményességére, doktori $(\mathrm{PhD})$ értekezés

[12] http://www.doktori.hu/index.php?menuid=193\&vid=12695 (letöltés dátuma: 2014.12.05.)

[13] Kotonen, U., Lahtinen, H., Savonen, M-L, Suomäki, A. \& Tuominen, U. (2012): Process and methods of competence management and development. In Ulla Kotonen, Anu Suomäki (eds.): competence development of logistics centers, Lahti University of Applied Sciences, 22-28.o.

[14] Központi Statisztikai Hivatal (KSH) (2014): Statisztikai Tükör 2014/30.

[15] Randstad (2014): Randstad Workmonitor wave 3, 2014 incl. quarterly mobility, job change and job satisfaction. Global report, Group communications, Randstad Holding nv, September 2014

[16] Vicsek, T. (2014): Why do we live in hierarchies? Multi-level hierarchical networks of connections in life. XXII. MLBKT Kongresszuson elhangzott előadás, Siófok, 2014. november 13.

[17] Világgazdaság (2015): Drónokat vetne be az Alibaba. 2015. február 6., 47. évfolyam, 25. (11534) szám, 9. oldal 